\title{
Gastronomy and Hospitality Enterprise Image in Guiuan Eastern Samar, Philippines
}

\author{
Jordan M. Cabaguinga ${ }^{*}$, Teresita Villa G. Lacabab \\ a College of Hospitality Management, Eastern Samar State University, Guiuan Campus - Philippines \\ ${ }^{b}$ College of Business Management and Accountancy, Eastern Samar State University, Guiuan Campus - Philippines
}

\section{A R T I C L E I N F O}

\begin{tabular}{l}
\hline Article history: \\
Received on: 07 December 2021 \\
Revised on: 19 December 2021 \\
Accepted on: 22 December 2021 \\
Published on: 03 February 2022 \\
\\
\hline Keywords: \\
Enterprise Image \\
Gastronomy Tourism \\
Local Products \\
Management \\
Promotion
\end{tabular}

\begin{abstract}
A B S T R A C T
Gastronomy tourism offers a unique touristic experience that positively affects other tourism industry sectors. This study focused on assessing gastronomy tourism and its relationship to the hospitality enterprise image of Guiuan Eastern Samar. A descriptive-correlational was applied with two sets of survey questionnaires with Cronbach alpha of 0.87. A total of 400 respondents participated in the survey. The data obtained were analysed using mean, standard deviation, and Pearson's correlation for the relationship of the variables. The results showed that gastronomy tourism of Guiuan, Eastern Samar, significantly contributed to the local pride and culture of the town as it preserves the local spice herbs and generates employment to the local community. Moreover, product, promotion, and management have a significant relationship to the hospitality enterprise image. Thus, it is recommended to maintain a reasonable price of the gastronomical products and provide sufficient information to encourage more patrons to get in touch with the different travel partners and operators in the region to create effective marketing tactics for the gastronomy tourism of the municipality. Likewise, traditional ways of developing the gastronomical products of the municipality must be preserved, as this serves as a competitive reinforcement for several hospitality enterprises.
\end{abstract}

Copyright $(2021$ iRAPA International Journal of Business Studies. Published by International Research and Publishing Academy - Pakistan. This is an open access article licensed under CC BY:

(https://creativecommons.org/licenses/by/4.0)

\section{Introduction}

Gastronomy tourism is one of the magnets of tourism that attracts tourists to visit and experience activities in a destination. Many destinations in the world utilize Gastro-tourism as marketing in attracting a large percentage of tourists. While on vacation, they consume food and beverages or decide what and where to eat (Richards, 2012). With the ever-changing needs, preferences, and wants of travellers' the concept of creative tourism has now become globalized from the establishment of the Creative Tourism Network in 2010 and the development of different innovative programs around the world (Fernandes and Rachao, 2014). With that, UNWTO published a report outlining the crucial links between intangible culture and tourism where tangible heritage comprises of so many different iconic sites that drive tourism growth, such as popular culture, traditional and gastronomy that provides essential support for the development of tourism and in themselves act as distinguishing features of a destination ( $\mathrm{Du}$ Cros, 2013). It is within the context that the Organization for Economic Cooperation and Development recognizes gastronomy tourism as an essential component of creative tourism and a part of the intangible heritage that provides a vital link for tourism. In the Philippines,

\footnotetext{
* Corresponding author: Jordan M. Cabaguing, College of Hospitality

Management, Eastern Samar State University, Guiuan Campus - Philippines

E-mail addresses: jcabaguing20@gmail.com

DOI: https: / / doi.org/10.48112/iijbs.v2i1.101

Copyright (C) 2021 iRAPA International Journal of Business Studies

Published by International Research and Publishing Academy

This is an open access article licensed under CC BY

(https://creativecommons.org/licenses/by/4.0)
}

How to cite:

Cabaguing, J. M., \& Lacaba, T. V. G. (2021). Gastronomy and Hospitality Enterprise Image in Guiuan Eastern Samar, Philippines. iRAPA International Journal of Business Studies, 2(1), 01-06. https://doi.org/10.48112/iijbs.v2i1.101 
gastronomy tourism is considered an economic bright spot wherein several programs and projects of the Department of Tourism have focused on the sector, and even Research and Development of it is emphasized. Supportively, the Asian Institute of Management states that gastronomy tourism in the Philippines is now getting a world's recognition as one of the best cuisines in the world as it provides instant gratification and creates instantaneous memories for travelers. Hence, tourists visit the Philippines for its historical sites and natural wonders and to experience the unique flavors of the country's food to offer. Indeed, it is one of the crucial components of cultural tourism for the way food is prepared, and the technique it has is often passed down from one generation to the next (Ramli et al., 2015; Zahari et al., 2014). Food consumption is influenced directly by factors such as taste, satisfaction, cost, health care, convenience that generates a pattern of behavior, and a manifestation of human identity.

Every country has its own unique and exclusive gastronomic customs on how to prepare, eat, and serve (Horng \& Tsai, 2010), which drives a tourist to visit the culture (Smith, 2014). Sanchez and Lopez (2012) clarified that food quality is becoming a crucial factor affecting consumers. Mamoon (2016) pointed out in his study that cultural experience is the primary motivation for tourists to experience local food. Such a presentation plays a vital role in the tourist's mind while visiting a specific destination. When new destinations are visited, this behavior pattern of tourists changes because food is, of course, an essential part of any travel experience (Scott \& Duncan, 2017). With this, it is not surprising that gastrotourism ranks third among the main reasons tourists visit a destination, after cultural motive and nature.

Furthermore, it is a growing phenomenon because food allocation is the third in the rank of tourist expenditure and the main reason tourists go on holiday for a cultural experience, which includes culinary tourism (Barleanu, 2013). However, it also provides opportunities and job creation and development to local economies, which positively affect other sectors. It is also a significant contributor to overcoming seasonality (UNWTO, 2017). Additionally, Hall (2012) point out that gastronomy is essential for providing food directly to tourists, such as hotels, restaurants, and attractions. Still, it also has a significant economic impact throughout the food supply chain, primarily supplied locally.

Guiuan, Eastern Samar, is considering tourism as a driver towards reducing poverty in the province and an opportunity for economic sustainability. New programs, laws, and projects are now at phase for the development of the industry, which contains cultural preservation, natural and other tangible and intangible heritage. The gastronomic experiences to a sustainable economy, destination attractiveness, and local cultural preservation have not been explored. At the same time, a limited amount of literature has discussed to what extent gastronomy tourism contributes to developing a particular tourism destination and how the local government can play a significant role in its development. Therefore, to bridge the gap between the potentiality and the contribution the industry brings to Guiuan Eastern Samar. This study will provide relevant information to assist the local government in its journey towards a more progressive town through its cultural aspects, which can be experienced in its local delicacies and foods.
This research focused on determining the relationship between gastronomy tourism and hospitality enterprise image. Specifically, it aimed to know the status of the gastronomy tourism of Guiuan, Eastern Samar, considering the product, price, location, promotion, and management. Also, to identify which measuring variables have a significant relationship to the hospitality enterprise image. Finally, to propose activities to improve gastronomy and hospitality enterprise image in Guiuan, Eastern Samar.

\section{Material \& Methods}

The study utilized the descriptive-correlational to determine the association and relationship of the variables. The design is appropriate to the study; hence, the primary purpose is to identify the significant relationship between gastronomy tourism and hospitality enterprise image. It is also used to determine how different variables were related to each other in the population of interest.

The participants of the study were composed of the international and local tourists who visited hospitality establishments in Guiuan, Eastern Samar were local delicacies of the town is being offered. Also, the owners and employees of these establishments. It utilized convenience sampling, and 400 participants participated in the study. In the collection of data, an introductory letter stating the purpose of the study and how the data will be treated as provided to the participants as well as the informed consent form that stated information like the study procedure, confidentiality, protection of the data, and contact information of both the researchers to provide for adequate ethical considerations and information. Respondents were also informed that they could refuse to join or withdraw from the study at any time without question or consequence.

Two sets of survey questionnaires were utilized in the study. The first set gathers information about the status of the gastronomy tourism of Guiuan, Eastern Samar. While the second set evaluates the contribution of gastronomy tourism to the hospitality enterprise image adapted from Hoghgi et al. (2014) and Trihas et al. (2016) slightly modified to suit the current study. The field experts validated the survey instrument to ensure the accuracy of the content and the suitability to the local environment. It has a total of 0.87 Cronbach alpha value which, according to Taber (2018), is an acceptable alpha for statistical research.

The obtained data from the survey were tallied and analyzed by employing mean, standard deviation, and Pearson's correlation for the relationship of the variables. The five-Likert scale was used to interpret certain responses of the study. 3.25-4.00 - Strongly Agree, 2.503.24-Agree, 1.75-2.49 - Disagree, and 1.00-1.74Strongly Disagree.

\section{Results \& Discussion}

The results and discussion below are a presentation of the respondents' responses regarding the status and contribution of gastronomy tourism to hospitality enterprise image. Gastronomy status includes the qualifying variables of Product, Location, Promotion, and Management. The data is presented in mean and 
standard deviation with corresponding interpretation to determine the participants' assessment and homogeneity of the responses.

Table 1

\begin{tabular}{|c|c|c|c|c|}
\hline Items & Mean & SD & Interpretation & Rank \\
\hline $\begin{array}{l}\text { Local food and delicacies, } \\
\text { drinks, beverages are } \\
\text { delicious and in good taste. }\end{array}$ & 3.10 & 0.86 & Agree & 1 \\
\hline Good scent, odour, and smell. & 2.96 & 0.79 & Agree & 10 \\
\hline $\begin{array}{l}\text { The Guiuananon local foods } \\
\text { and delicacies are quality } \\
\text { foods. }\end{array}$ & 2.94 & 0.81 & Agree & 13 \\
\hline $\begin{array}{c}\text { It offers a variety of } \\
\text { Guiuananons' local food and } \\
\text { delicacies. }\end{array}$ & 2.99 & 0.88 & Agree & 6 \\
\hline $\begin{array}{l}\text { Exclusive food items } \\
\text { (Available in Guiuan only). }\end{array}$ & 3.02 & 0.88 & Agree & 5 \\
\hline $\begin{array}{l}\text { Hygiene and cleanliness are } \\
\text { evident in the food } \\
\text { preparation and presentation. }\end{array}$ & 3.03 & 0.92 & Agree & 4 \\
\hline $\begin{array}{l}\text { It offers seasonal food items } \\
\text { which are available in a } \\
\text { limited time only. }\end{array}$ & 2.96 & 0.87 & Agree & 10 \\
\hline $\begin{array}{l}\text { Attractive presentation and } \\
\text { appearance }\end{array}$ & 2.95 & 0.88 & Agree & 12 \\
\hline $\begin{array}{c}\text { Local foods and delicacies } \\
\text { have an easy recognizable } \\
\text { name. }\end{array}$ & 2.96 & 0.85 & Agree & 10 \\
\hline The foods are good for health. & 2.98 & 0.85 & Agree & 7 \\
\hline $\begin{array}{l}\text { Sophisticated preparation } \\
\text { method. }\end{array}$ & 2.96 & 0.84 & Agree & 10 \\
\hline $\begin{array}{l}\text { Quality, freshness of } \\
\text { ingredients which are } \\
\text { available within the locality. }\end{array}$ & 3.06 & 0.88 & Agree & 3 \\
\hline $\begin{array}{l}\text { Clear information of } \\
\text { ingredients, nutrition and } \\
\text { allergy }\end{array}$ & 3.06 & 0.88 & Agree & 3 \\
\hline Food safety is being practiced. & 2.87 & 0.86 & Agree & 14 \\
\hline Overall Mean & 2.99 & 0.86 & Agree & \\
\hline
\end{tabular}

It is shown in table 1 that all of the items are rated by the respondents as "Agree." However, the item "Local food and delicacies, drinks, and beverages are delicious and in good taste" obtained the highest mean score of 3.10, which means "Agree" in the qualitative description with a standard deviation of 0.86 . While the item "Food safety is being practiced" got the lowest mean rating of 2.87 , which means "Agree" with a standard deviation of 0.86 , which signifies a homogenous response from the respondents. The overall mean rating of 2.99 which interpreted as "Agree" in the qualitative description with a standard deviation of less than 1.0. The result indicates that the local cuisine of Guiuan, Eastern Samar, meets the taste of the tourists. However, there is a need to emphasize food safety, specifically in the preparation of those cuisines. According to Horng \& Tsai (2010), gastronomic preparation and servings give the drives to tourists to visit the destination. As added by Sanchez \& Lopez (2012) food quality is becoming a crucial factor that significantly affects consumers. As such, a presentation plays a vital role in the mind of the tourist while visiting a specific destination.
Table 2

\begin{tabular}{|c|c|c|c|c|}
\hline Items & Mean & SD & Interpretation & Rank \\
\hline $\begin{array}{c}\text { It has a reasonable price for } \\
\text { the quality food. }\end{array}$ & 3.35 & 0.53 & Strongly Agree & 7 \\
\hline $\begin{array}{l}\text { It has a reasonable price for } \\
\text { the quality of the service. }\end{array}$ & 3.41 & 0.51 & Strongly Agree & 3 \\
\hline $\begin{array}{l}\text { It has a reasonable price for } \\
\text { portion, amount of food. }\end{array}$ & 3.49 & 0.52 & Strongly Agree & 1 \\
\hline Special offering for purchase. & 3.38 & 0.51 & Strongly Agree & 5 \\
\hline $\begin{array}{l}\text { Offers special discount with } \\
\text { purchase. }\end{array}$ & 3.39 & 0.50 & Strongly Agree & 4 \\
\hline $\begin{array}{l}\text { Free additional product or } \\
\text { service with purchase. }\end{array}$ & 3.41 & 0.53 & Strongly Agree & 3 \\
\hline Overall reasonable price. & 3.37 & 0.49 & Strongly Agree & 6 \\
\hline Overall Mean & 3.40 & 0.51 & $\begin{array}{l}\text { Strongly } \\
\text { Agree }\end{array}$ & \\
\hline
\end{tabular}

Legend: 3.25-4.00 - Strongly Agree, 2.50-3.24-Agree, 1.75-2.49 - Disagree, and 1.00-1.74- Strongly Disagree

The result shown in table 2 indicates that the respondents strongly agreed about the different items indicated under the price qualifying variable. The item "It has a reasonable price for portion amount of food" got the highest mean rating of 3.49 , followed by items "It has a reasonable price for the quality of the service" and "Free additional product or service with purchase." While the item "It has a reasonable price for the quality food" earned the lowest mean score of 3.35. The overall mean rating is 3.40, which is interpreted as "Strongly Agree" in the qualitative description with a standard deviation less than 1.0 that indicates homogeneity of the responses among the respondents. The result indicates that the gastronomical products of Guiuan, Eastern Samar have a reasonable price from quality production to its delivery of service as being shown in the result above.

Table 3

\begin{tabular}{|c|c|c|c|c|}
\hline Items & Mean & SD & Interpretation & Rank \\
\hline Convenient Location. & 3.37 & 0.60 & Strongly Agree & 2 \\
\hline $\begin{array}{l}\text { Accessible by public } \\
\text { transportation. }\end{array}$ & 3.36 & 0.59 & Strongly Agree & 3 \\
\hline $\begin{array}{l}\text { Understandable menu (with } \\
\text { picture and content). }\end{array}$ & 2.45 & 0.94 & Agree & 10 \\
\hline Very Good Service. & 3.28 & 0.52 & Strongly Agree & 6 \\
\hline $\begin{array}{l}\text { Included in tour packages } \\
\text { itinerary. }\end{array}$ & 2.27 & 0.83 & Agree & 11 \\
\hline $\begin{array}{l}\text { Offers unique cultural } \\
\text { experiences. }\end{array}$ & 3.29 & 0.54 & Strongly Agree & 5 \\
\hline $\begin{array}{l}\text { Presenting special and } \\
\text { exciting cooking method. }\end{array}$ & 3.13 & 0.62 & Agree & 8 \\
\hline $\begin{array}{l}\text { Readily available at your } \\
\text { convenient time. }\end{array}$ & 3.04 & 0.58 & Agree & 9 \\
\hline Good atmosphere. & 3.39 & 0.49 & Strongly Agree & 1 \\
\hline Good layout and decoration. & 3.27 & 0.54 & Strongly Agree & 7 \\
\hline $\begin{array}{l}\text { Accepting many methods of } \\
\text { payment. }\end{array}$ & 3.33 & 0.58 & Strongly Agree & 4 \\
\hline Overall Mean & 3.10 & 0.62 & Agree & \\
\hline
\end{tabular}


Legend: 3.25-4.00 - Strongly Agree, 2.50-3.24-Agree, 1.75-2.49 - Disagree, and 1.00-1.74- Strongly Disagree.

As shown in the table above, that out of 11 items under the dimension of Location. Seven (7) of them were rated as "Strongly Agree" comprises the items "Convenient Location", "Accessible by public transportation," "Very Good Service," "Offers unique cultural experiences," "Good atmosphere", and "Good layout and decoration" and "Accepting many methods of payment" with a mean rating of $3.37,3.36,3.28,3.39,3.27$, and 3.33 respectively. All of the items have a less than 1.0 standard deviation, which indicates homogeneity of the responses. The result shows that the gastronomical products of Guiuan, Eastern Samar have an excellent atmosphere, convenient location, and accessible by public transportation, as being shown above. However, these locations/places should actively be included in the making of the tour itinerary.

Table 4

\begin{tabular}{|c|c|c|c|c|}
\hline Items & Mean & SD & Interpretation & Rank \\
\hline $\begin{array}{l}\text { Sufficient information for } \\
\text { local food and drink. }\end{array}$ & 3.16 & 0.72 & Agree & 9 \\
\hline $\begin{array}{l}\text { Frequency of information for } \\
\text { local food and drinks. }\end{array}$ & 3.27 & 0.63 & Strongly Agree & 6 \\
\hline $\begin{array}{l}\text { Timeline updates of } \\
\text { information. }\end{array}$ & 3.44 & 0.55 & Strongly Agree & 3 \\
\hline $\begin{array}{l}\text { Information from mass } \\
\text { media (TV, radio, and } \\
\text { newspaper). }\end{array}$ & 3.45 & 0.55 & Strongly Agree & 2 \\
\hline $\begin{array}{l}\text { Information from face-to- } \\
\text { face communication (travel } \\
\text { agency, travel exhibition, } \\
\text { and tourist centers'). }\end{array}$ & 3.45 & 0.59 & Strongly Agree & 2 \\
\hline $\begin{array}{l}\text { Information from special } \\
\text { interest media (Internet, } \\
\text { website, magazine, and } \\
\text { guide book). }\end{array}$ & 3.31 & 0.61 & Strongly Agree & 4 \\
\hline $\begin{array}{l}\text { Information from trusted } \\
\text { persons (family, friends, and } \\
\text { colleague). }\end{array}$ & 3.25 & 0.64 & Strongly Agree & 8 \\
\hline $\begin{array}{l}\text { Information from trusted } \\
\text { persons (family, friends, and } \\
\text { colleague). }\end{array}$ & 3.25 & 0.64 & Strongly Agree & 8 \\
\hline $\begin{array}{l}\text { There are information that } \\
\text { supports before coming to } \\
\text { Guiuan, Eastern Samar. }\end{array}$ & 3.25 & 0.61 & Strongly Agree & 8 \\
\hline $\begin{array}{l}\text { There are information that } \\
\text { supports while in Guiuan, } \\
\text { Eastern Samar. }\end{array}$ & 3.27 & 0.63 & Strongly Agree & 6 \\
\hline Overall Mean & 3.32 & 0.61 & $\begin{array}{c}\text { Strongly } \\
\text { Agree }\end{array}$ & \\
\hline
\end{tabular}

Legend: 3.25-4.00 - Strongly Agre

and 1.00-1.74- Strongly Disagree

Most of the items above were rated as "Strongly Agree". However, the items "Information from mass media (TV, radio, and newspaper)" and "Information from face-to-face communication (travel agency, travel exhibition, and tourist centers)" got the highest mean rating of 3.45 , While the item"Sufficient information for local food and drinks" obtained the lowest mean score of 3.16 , which is interpreted as "Agree". The result directs to the need to provide more information about Guiuananon's local foods, delicacies, and beverages to any media and social platforms for tourists to be much more aware of the gastronomical offerings of the municipality as being shown on the lowest mean rating score on the table above.

Table 5

Management

\begin{tabular}{|c|c|c|c|c|}
\hline Items & Mean & SD & Interpretation & Rank \\
\hline $\begin{array}{l}\text { No coordination in the food } \\
\text { marketing system in } \\
\text { tourism of Guiuan, } \\
\text { Eastern Samar. }\end{array}$ & 3.28 & 0.69 & Strongly Agree & 2 \\
\hline $\begin{array}{l}\text { Low quality of laws and } \\
\text { regulations regarding local } \\
\text { food supply in tourism. }\end{array}$ & 3.03 & 0.87 & Agree & 4 \\
\hline $\begin{array}{l}\text { Low quality or non-existent } \\
\text { promotion of local food of } \\
\text { Guiuan, Eastern Samar. }\end{array}$ & 2.88 & 0.55 & Agree & 10 \\
\hline $\begin{array}{l}\text { Lack of financial support } \\
\text { from the local government } \\
\text { for local food projects. }\end{array}$ & 2.92 & 0.90 & Agree & 9 \\
\hline $\begin{array}{l}\text { Insufficient local food } \\
\text { event. }\end{array}$ & 2.95 & 0.90 & Agree & 8 \\
\hline $\begin{array}{l}\text { Lack of food information } \\
\text { for tourists. }\end{array}$ & 3.01 & 0.88 & Agree & 6 \\
\hline $\begin{array}{l}\text { Low quality offering in } \\
\text { local hotels and } \\
\text { restaurants. }\end{array}$ & 2.99 & 0.87 & Agree & 7 \\
\hline $\begin{array}{l}\text { Quality of local food } \\
\text { product is highly given an } \\
\text { emphasis. }\end{array}$ & 3.08 & 0.83 & Agree & 3 \\
\hline $\begin{array}{l}\text { Availability of local food } \\
\text { products is highly evident. }\end{array}$ & 3.30 & 0.86 & Strongly Agree & 1 \\
\hline $\begin{array}{l}\text { There is a high tourists' } \\
\text { interest for local foods. }\end{array}$ & 3.01 & 0.79 & Agree & 6 \\
\hline Overall Mean & 3.04 & 0.81 & Agree & \\
\hline
\end{tabular}

The item "Availability of local food products is highly evident" obtained the highest mean rating of 3.30 with 0.86 standard deviations. While the item "Low quality or non-existent promotion of local food of Guiuan, Eastern Samar" got the lowest mean rating of 2.88 , which is interpreted as "Agree" in the qualitative description. It is reflected in the result that tourists strongly agreed that there is no coordination of local food marketing of Guiuan, Eastern, a reason that there is a lack of promotional campaign of these local cuisines of the municipality. It further shown in the result the vital role of the local government in the realization of introducing the gastronomical tourism of the municipality to a broader number of markets. 
Table 6

\begin{tabular}{|c|c|c|c|c|}
\hline Items & Mean & SD & Interpretation & Rank \\
\hline Competitive reinforcement. & 3.33 & 0.75 & Strongly Agree & 1 \\
\hline $\begin{array}{l}\text { Image improvement and } \\
\text { reputation creation for the } \\
\text { enterprises. }\end{array}$ & 3.24 & 0.78 & Agree & 4 \\
\hline $\begin{array}{l}\text { Diversification and } \\
\text { enrichment of the industry } \\
\text { product offerings. }\end{array}$ & 3.01 & 0.78 & Agree & 11 \\
\hline Increased bookings. & 3.15 & 0.84 & Agree & 7 \\
\hline Customer loyalty. & 3.14 & 0.86 & Agree & 8 \\
\hline Increased turnover. & 2.94 & 0.84 & Agree & 12 \\
\hline $\begin{array}{l}\text { Attract new customers of } \\
\text { culinary interest. }\end{array}$ & 3.02 & 0.78 & Agree & 10 \\
\hline $\begin{array}{l}\text { Increase customer } \\
\text { satisfaction. }\end{array}$ & 3.15 & 0.67 & Agree & 7 \\
\hline $\begin{array}{l}\text { Creation of new } \\
\text { partnership with tour } \\
\text { operators }\end{array}$ & 3.29 & 0.78 & Strongly Agree & 3 \\
\hline $\begin{array}{l}\text { Better promotion of the } \\
\text { industry through } \\
\text { promotional actions of the } \\
\text { local government. }\end{array}$ & 3.22 & 0.72 & Agree & 5 \\
\hline $\begin{array}{l}\text { Creation of a unique and } \\
\text { authentic experience for } \\
\text { visitors. }\end{array}$ & 3.13 & 0.70 & Agree & 9 \\
\hline $\begin{array}{c}\text { Promotion and } \\
\text { enhancement of } \\
\text { Guiuananon's culinary } \\
\text { heritage and identity. }\end{array}$ & 3.30 & 0.71 & Strongly Agree & 2 \\
\hline Overall Mean & 3.16 & 0.77 & Agree & \\
\hline
\end{tabular}

Legend: 3.25-4.00 - Strongly Agree, 2.50-3.24-Agree, 1.75-2.49 - Disagree,
and 1.00-1.74- Strongly Disagree

Out of twelve items under enterprise image three was rated as "Strongly Agree," namely the "Competitive reinforcement," "Promotion and enhancement of Guiuananon's culinary heritage and identity," and Creation of new partnership with tour operators" with $3.33,3.30$, and 3.29 mean rating respectively. All of the items have a less than 1.0 standard deviation, which implies homogeneity of the responses. The result revealed that gastronomy tourism is one of the competitive advantages of several hospitality enterprises, which could qualify them among the other business entity in the province. Okumuş et al. (2007); Horng \& Tsai (2010); Karim \& Chi (2010) expressed that food has a significant role in competing with other destinations for the destinations that are known with their cuisines has a great chance to link with the cuisine itself. As added, Nelson (2016) showed that food tourism could create a unique and robust image that motivates tourists of intention to visit and revisit the destination. It gives a distinct advantage to that destination place. Among others, gastronomic tourism is very crucial in the sense that it helps a particular destination to shine and get a reputation among others, for it provides a unique trip that simply shows an essential symbolic meaning besides being a physiological need (Caliskan, 2013). With this, it is now considered as one of the crucial indicators of tourists' status that relates to what, where, when, and with whom they eat; therefore, image-making of gastrotourism details should be given tremendous special attention as they are vital in attracting more visitors (Sahin, 2015).

Table 7

Relationship between Gastronomy and Hospitality enterprise Image

\begin{tabular}{|c|c|c|c|c|}
\hline \multicolumn{5}{|c|}{ Enterprise Image } \\
\hline & r-value & Interpretation & p-value & Interpretation \\
\hline Location & 0.15 & $\begin{array}{c}\text { Slight } \\
\text { correlation }\end{array}$ & .661 & Not Significant \\
\hline Product & 0.22 & $\begin{array}{c}\text { Low } \\
\text { correlation }\end{array}$ & $.000^{* * *}$ & Significant \\
\hline Price & 0.40 & $\begin{array}{l}\text { Moderate } \\
\text { correlation }\end{array}$ & .689 & Not Significant \\
\hline Promotion & 0.80 & $\begin{array}{c}\text { High } \\
\text { correlation }\end{array}$ & $.005^{* *}$ & Significant \\
\hline Management & 0.20 & $\begin{array}{c}\text { Low } \\
\text { correlation }\end{array}$ & $.000^{* * *}$ & Significant \\
\hline
\end{tabular}

**. Correlation is significant at the 0.01 level (2-tailed).

Legend: Significant at $\mathrm{p}$-value $<0.05$

The table revealed that out of the five measuring variables under gastronomy status, only three were significant they are the Product, Promotion, and Management. The variable Product has an r-value of 0.22 , having a lower correlation, and a p-value of .000, which is highly significant to 0.05 . While, Promotion has the $\mathrm{r}$-value of 0.980 , having a p-value of .005, which is interpreted as significant, and Management has the $r-$ value of 0.20 and a $p$-value of 0.000 . The result indicates that the gastronomical product, promotion, and management have a significant relation to the hospitality enterprise image. It further denotes the exceptional contribution of gastronomy tourism to hospitality establishments of Guiuan, Eastern Samar, specifically those who offer local cuisines. It further signifies those owners should work hand in hand with the local government how the local cuisines of Guiuan will further be developed.

\section{Conclusion}

Gastronomy tourism of Guiuan, Eastern Samar, from its food, beverages, and delicacies, meets the taste of the tourists and has a reasonable price. The location where these local cuisines are offered (local F\&B operators) have a pleasant atmosphere. The information drive about the gastronomy tourism of the municipality should be strengthened to encourage more travellers. More so, a strong linkage in the marketing system for gastronomy should be emphasized by the local government and other stakeholders as there is low promotional quality. Gastronomy tourism significantly contributed to the development of local pride and culture of Guiuananons as it preserves the local spice herbs and generates employment, and increases the standard of living for the local community. Also, entrepreneurship development among the local residents. Nevertheless, it significantly adds to the image of local hospitality enterprises as a competitive reinforcement and a way for them to have a new partnership with different tour operators, as well as a better promotional strategy of the organization and a creation of unique and authentic experiences to tourists. Trainings and development to be provided to hospitality 
enterprises includes Food Safety Practices with HACCP Procedures, Preparation of local cuisines considering the skills in plating and garnishing, Product Pricing Strategy, Ergonomics and Facilities Planning, Customer Relations Management; and Developing Comprehensive Marketing Techniques.

\section{References}

Bârleanu, V.,( 2013). Gastronomy Tourism in Romania. http://www.sursazilei.ro/comisia-europeana-lansatun-sitepentru- (Accessed October 25, 2020)

Caliskan, O., (2013). Gastronomic Identity in Terms of Destination Competitiveness and Travel Motivation. Journal of Tourism and Gastronomy.

Du Cros, H. (2013). Tourism and Intangible Cultural Heritage. Madrid: UNWTO.

Fernandes, C. and Rachão, S. (2014) Reinventing Tourism at a traditional Cultural Tourism Destination: A Case Study of Viana do Castelo. International Journal of Business and Globalization, 12, 281-296.

Hall, C.M. (2012). Boosting food and tourism-related regional economic development. In OECD, Food and the Tourism Experience: The OECD-Korea Workshop, OECD Studies on Tourism, OECD Publishing: 49-62.

Horng, J. S. \& Tsai, C.T.(S) (2010). Government Websites for Promoting East Asian Culinary Tourism: A CrossNational Analysis. Tourism Management .31, 74-85.

Karim, A.S.; Chi, C. G. Q. (2010). Culinary Tourism as a Destination Attraction: An Empirical Examination of Destinations' Food Image. Journal of Hospitality Marketing \& Management, 19: (6), 531-555.

Mamon,Allan (2016). Exploring the Relationship between local food consumption and Intentional Loyalty. Journal of Tourism-studies and Research tourism. Vol. 3 Issue 21, pp 33-38.

Nelson, V.,( 2016). Food and Image on the official visitor site of Houston, Texas. Journal of Destination Management and Marketing, 5, pp.133-140.

Okumus, B.; Okumus, F.; Mckercher, B. (2007). Incorporating Local and İnternational Cuisines in the Marketing of Tourism Destinations: The Cases of Hong Kong and Turkey. Tourism Management, 28: (1), 253261.

Privitera, Donatella, Nedelcu, Adrian, Nicula, Virgil (2018). Gastronomic and Food Tourism as an Economic Local Resource: Case Study from Romania and Italy. Geo Journal of Tourism and Geosites, Vol. 21, pp 143-157

Ramli, A. M., Zahari, M. S. M., \& Talib, S. A. (2014). Identification of Food Heritage: Food Identity Analysis on Demographic Background. Research \& Innovation Conference for the Graduate Students in Social Sciences 2014.

Richards, G. (2012). An overview of food and tourism trends ad policies. In OECD (Eds.), Food and tourism experience: the OECD-Korea Workshop (pp. 13-43). OECD Studies on Tourism. Paris: OECD Publishing.

Rinaldi, Chiara (2017). Food and Gastronomy for Sustainable Place Development: A Multidisciplinary Analysis of Different Theoretical Approaches. University of Gothenburg.

Sahin, E., (2015). Research for Analyzing on using traditional foods as a promotional factor in brochures. University. Institute of Social Sciences, Department of Gastronomy and Culinary Arts.

Sanchez-Cañizares, S.M. \& Lopez-Guzmán, T. (2012). Gastronomy as a Tourism Resource: Profile of the
Culinary Tourist. Current Issues in Tourism 15 (3), 229-245.Sciences, MA Thesis, Ankara.

Scott, D., Duncan, T., (2015), Back to the future: The affective power of food in reconstructing a tourist imaginary, in I. Yeoman, U. McMahon-Beattie, K. Fields, J. N. Albrecht \& K. Meethan (Eds), The future of Food Tourism, Foodies, Experiences, Exclusivity, Visions and Political Capital, p. 143- 156, Channel View Publications, Bristol.

Taber,Keith (2018). The Use of Cronbach's Alpha when Developing and Reporting Research Instruments in Science Education. Research in Science Education, vol. 48, 1273-1296. 